\title{
Impact Of After Sales Service On Consumer Satisfaction And Retention. A Study of LG Electronics in Ibadan, Nigeria.
}

\author{
Ladokun Isaac .O, Adeyemo S.A,Ogunleye P.O \\ Department Of Marketing The Polytechnic, Ibdan \\ Department Of Business Administration Osun State Polytechnic Iree \\ Department Of Business Administration Osun State Polytechnic Iree
}

\begin{abstract}
This study examined the impact of after sales service on customer satisfaction and retention with special reference to LG electronics in Ibadan, Nigeria. The population of the study covered selected distributors and customers of LG Electronics in Ibadan. The sample size for this study was sixty (60) respondents who were randomly selected from ten (10) LG electronics distributors and fifty (50) of their customers respectively. The instrument used in this study is a close-ended questionnaire that was designed by the researchers.Ordinary least squares multiple regression analysis was used to analyze the data. The result showed that the predictor variables (i.e Product delivery, installation and warranty) were significantly joint predictors of customer satisfaction and retentionwith $\left.F(3,57)=123.32 ; R^{2}=0.875 ; P<.05\right)$. The predictor variables jointly explained $87.5 \%$ of customer satisfaction and retention, while the remaining $12.5 . \%$ could be due to the effect of extraneous variables. Subsequently, recommendation was made to the management of $L G$ electronics to set up more after sales service departments to the existing ones with experience staff with the view of developing long term relationship with the customers.
\end{abstract}

Key words: After sales service, Warranty, Installation, Delivery and LG electronics

Accepted Date: 01 June 2013

\section{Introduction}

After sales service has become an important marketing tool for the manufacturing industry globally, Nigeria inclusive. A rapidly changing business environment, increased use of technology, higher market competition, and higher potential profits in after sales service has changed the way companies view after sales services (Muhammad et al, 2011). It is no longer treated as a cost center, but instead, has become a major profit source with profitability ranging up to $45 \%$ of corporaterevenues for many business environments(Saccani, et al., 2007).

After sales service involves a continuous interaction between the service provider and thecustomer throughout the post-purchase product life cycle. At the time the product issold to the customer, this interaction is formalized by a mutually agreed warranty orservice contract. The exact terms of the warranty or service contract, the characteristicsof the customer base, and the nature of the sold product influence the after sales servicestrategy of the service provider (Cohen et al., 2006; Oliva and Kallenberg, 2003) as cited in Muhammed, et al (2011).

Goffin and New, (2001) discovered that after-sales services maximize the value extracted bycustomers over the entire product life cycle. Kurata and Nam, 2010; and Ahn and Sohn,( 2009)) agreed that after-sales services can create sustainable relationships withcustomers and contribute significantly to customer satisfaction by offering different after-sales services during the various stages of the primary product lifecycle, the provider can ensure product functionality and thereby customer satisfaction. This may lead to a fruitful relationship between the provider and the customer over time, allowing for more transactions. It is on this note that this research paper wishes to investigate the impact of after sales service dimensions on customer satisfaction and retention with special reference to LG Electronics in Ibadan metropolis, Nigeria.

\section{Theoretical And Empirical Background}

After-sales service has emerged as a major source of competitive maneuvering, so firms strive for competitive advantages with their after-sales service portfolio to differentiate offers from competitors (Goffin, 1994; Slater, 1996; as cited in Ruben, 2012). After-sales services are an important marketplace differentiator because primary products are often physically comparable (Ruben, 2012). Saccani, et al., (2007) defined aftersales service for manufactured goods as the set of activities taking place after the purchase of the product, devoted to supporting customers in the usage and disposal of goods. Rigopoulou, et al., (2008)described aftersales services as services that are provided to the customer after the products have been delivered. Cavalieri, et 
al., (2007) viewed after-sales service as those activities occurring after the purchase of the product and devoted to supporting the customer in the usage and disposal of the goods. Urbaniak, (2001) defined after sales service as those activities that enhance or facilitate the role and use of the product. (Asugman, et al., 1997) defined after sales service as those activities in which a firm engages after purchase of its product that minimize potential problems related to product use, and maximize the value of the consumption experience. Ehinlanwo and Zairi, (1996) also defined after sales service as "all activities geared towards maintaining the quality and reliability of the car carried out after the customer has taken delivery with the goal of ensuring customer satisfaction.' According to Ruben, (2012) after-sales services is the sum of activities taking place after the purchase of a product which:

- $\quad$ ensure that a product is available for trouble-free use over its useful life span andguarantee the continuous availability of goods (preventive maintenance)

- $\quad$ replace failed products in a timely and cost-effective manner (reactive maintenance)

- $\quad$ create competitive advantage for the customer (value added services).

Raddats, (2011) is of opinion that customers are no longer demand just for a product but also a comprehensive solution for their problem; they are increasingly moving away from requesting for a specific product to requesting for a certain service package (including the original purchase and all aftermarket needs) instead. Chien, (2005) also agreed that free basic after-salesservice plays an important role in attracting morecustomer attention in a market with severe brandcompetition. Offering adequate after-salesservice to customers has become a major generator ofrevenue, profit, and competency in modern industries(Cohen et al., 2006; Cohen and Kunreuther, 2007) as cited in Alirezaet al, (2011). Shaharudinet al (2009) examined the factors of after sales service, which affect customer satisfaction in the electronic market of Malaysia. After sales service was determined through delivery, installation and warranty. 100 respondents were sampled through closed ended questionnaire, while Ordinary Least Square was used to analyses the data. Results showed that delivery, installation and warranty has significant positive impact on the customer satisfaction and retention. Ruben, (2012) also agreed that after sales service significantly enhance the value of the product to its users. He noted that customers may decide to purchase a product based upon service and aftermarket considerations.

Rigopoulouet al, (2008) also examined the consequences of after sales service on customer satisfaction and retention. Data was collected through closed ended questionnaire, which was administered through telephone interviews from 420 respondents in Greece. The results show that after sales service has significant and positive impact on customer satisfaction and retention. They suggest that service marketing managers should understand the impact of after sales service on customer satisfaction and behavioural intentions. Gupta and Lehmann, (2007) in their study on the impact of after sales service on customer relationship and they discovered that after-salesservice is regarded as an important factor that has animpact on establishing good relationships with customers.Alexander et al., (2002) accepted the claim that returning customers are themost profitable ones, as they require less marketing effortand relationship building. They agreed that after-sales service acquires acritical role as a means to achieve customer satisfactionand retention.

Rosen and Surprenant(1998) studied whether after sales service is enough for the long relationship with customers. They selected two different industries with 220 respondents, while open ended questionnaire was used to collect the data. Both descriptive and qualitative analyses were used to analyze the data. Results showed that after sales service is marketing tool that create and establish long term relationship with customers through good communication and flexibility.Furthermore, excellent service may enhance the success rate of new products. Cohen et al., (2006) and Cohen and Whang, (1997) all of them believed that large number of extra after-sales service plans to consumers will lead to customer satisfaction and retention as well as higher profitability.

\subsection{BRIEF HISTORY OF LG ELECTRONICS}

\section{Founded as GoldStar}

1960's Produces Korea's first radios, TVs, refrigerators, washing machines, and air conditioners

1995 Renamed LG Electronics Acquires US-based Zenith

1997 World's first CDMA digital mobile handsets supplied to Ameritech and GTE in U.S. Achieves UL certification in U.S. Develops world's first IC set for DTV

1999 Establishes LG Philips LCD, a joint venture with Philips

2000 Launches world's first Internet refrigerator Exports synchronous IMT-2000 to Marconi Wireless of Italy Significant exports to Verizon Wireless in U.S.

2001 GSM mobile handset Exports to Russia, Italy, and Indonesia Establishes market leadership in Australian CDMA market Launches world's first Internet washing machine, air conditioner, and microwave oven 
2002 Under LG Holding Company system, separates into LG Electronics and LG Corporation Full-scale export of GPRS color mobile phones to Europe Establishes CDMA handset production line and R\&D center in China

2003 Enters Northern European and Middle East GSM handset market Achieves monthly export volume above 2.5 million units (July) Top global CDMA producer

2004 EVSB, the next-generation DTV transmission technology, chosen to be the U.S./Canada Industry standard by the US ATSC Commercializes world's first 55" all-in-one LCD TV Commercializes world's first 71" plasma TV Develops world's first Satellite- and Terrestrial-DMB handsets

2005 Becomes fourth-largest supplier of the mobile handsets market worldwide Develops world's first 3G UMTS DMB handset, 3G-based DVB-Hand Media FLO DMB Phone with time-shift function and DMB notebook computer Establishes LG-Nortel, a network solution joint venture with Nortel

2006 LG Chocolate, the first model in LG's Black Label series of premium handsets, sells 7.5 million units worldwide Develops the first single-scan 60" HD PDP module and 100-inch LCD TV Establishes strategic partnership with UL Acquires the world's first IPv6 Gold Ready logo

2007 Launches the industry's first dual-format, high-definition disc player and drive Launches $120 \mathrm{~Hz}$ Full HD LCD TV Demonstrated the world-first MIMO 4G-Enabled technologies with 3G LTE Won contract for GSMA's 3G campaign

2008 Introduces new global brand identity: "Stylish design and smart technology, in products that fit our consumer's lives." Posted No.1 spot in US frontloading washers in 5 consecutive quarters Unveiled the world's first Bluetooth headset combined mobile phone Unveiled the world's first Blu-ray network storage Developed the world's first LTE mobile modem chip Recorded over 100 million units of LG air conditioners in accumulated sales

2009 Became second-largest LCD TV provider worldwide Became third-largest supplier of mobile handsets market worldwide Became Global Partner and Technology Partner of Formula One

2010 Unveiled the world's first and fastest dual-core smartphone, LG OPTIMUS 2X Unveiled the world's first full LED 3D TVUnveiled the new E90 monitor, the company's slimmest LED monitor to date at just $7.2 \mathrm{~mm}$ in depthUnveiled the company's first ever Real 3D Sound Home Theater SystemUnveiled its latest, groundbreaking creations: the BIGIN, a largest-in-class washing machine with LG's proprietary 6 Motion Direct Drive; the iPRO, the largest, most energy efficient refrigerator in its class; the world's first solar Lightwave oven and the world's first KOMPRESSOR ${ }^{\text {TM }}$ vacuum cleaner

2011 Launched water treatment businss providing full-scale planning through total maintenance solutionsIntroduced CINEMA 3D Smart TV combining industry-leading 3D technology and smart TV capabilitiesLaunched water treatment business providing full-scale planning through total maintenance solutionsIntroduced CINEMA 3D Smart TV combining industry-leading 3D technology and smart TV capabilitiesUnveiled the world's first smart appliances delivering the consumer benefits of smart savings and smart convenienceIncreased investment in air conditioning solutions delivering a full lineup for residential through large industriesIntroduced LG Revolution TM, LG's first 4G smartphone followed by Optimus LTE, the company's best-selling 4G smartphone to date.

Source: www.lg.com (2013)

\section{Methodology}

The survey research design method was used in this study. It involves using a self-design questionnaire in collecting data from the respondents. The population of the study covered selected distributors and customers of LG Electronics in Ibadan.The sample size for this study was sixty (60) respondents who were randomly selected from ten (10) LG electronics distributors and fifty (50) of their customers respectively. The instrument used in this study is a close-ended questionnaire that was designed by the researcher. In order to establish the reliability of this instrument, a pilot study was carried out on a sample of eighty respondents, using a test - retest method. The result of the reliability test ware: customer performance and retention, 0.76 product delivery, 0.65 ; installation 0.82; and warranty, 0.71 respectively, are showing that the instrument is reliable. In confirming the validities of the instrument, face and content validities were ensured the instrument was given to professionals for scrutiny and evaluation. The procedure for analyzing the data was econometric procedure. Here the technique used was theordinary least squaremultiple regression analysis to test whether the after sales indices have impacted on the customer satisfaction and retention.

\subsection{HYPOTHESES FORMULATED}

Ho1. Product delivery has no significant effect on customer satisfaction and retention.

HoII. Installation has no significant effect on customer satisfaction and retention.

HoIII. Warranty has no significant effect on customer satisfaction and retention. 


\subsection{MODEL SPECIFICATION}

Model which specifies that customer satisfaction and retention is significantlyinfluenced by the after sales service indices (Product Delivery, Installation and Warranty)

is formulated as follows:

$\mathrm{CSR}=\mathrm{f}(\mathrm{PDR}, \mathrm{INS}, \mathrm{WRT})$

$\mathrm{LgCRS}=\beta 0+\beta 1 \mathrm{LnPDR}+\beta 2 \mathrm{LnINS}+\beta 3 \mathrm{LnWRT}$

Where;

The a priori expectation is $\beta 1, \beta 2, \beta 3>0$

$\mathrm{LgCRS}=$ Customer satisfaction and retention

LgPDR $=$ Product Delivery

LgINS= Installation

LgWRT $=$ Warranty

$\mathrm{U}=$ Disturbance Term

$\beta=$ Intercept

$\beta 1-\beta 3=$ Coefficient of the Independent Variables.

Note: All variables are in their natural logarithm form.

\section{Data Analysis And Interpretation}

Table 1.

\begin{tabular}{|l|l|l|l|l|l|l|l|l|}
\hline Variable & Coefficient & $\begin{array}{l}\text { Standard } \\
\text { Error }\end{array}$ & t-statistics & P & $\mathrm{R}^{2}$ & F & $\begin{array}{l}\text { P } \\
\text { Watson }\end{array}$ \\
\hline Lg PDR & 0.339 & 0.087 & 4.623 & $<.05$ & \multirow{2}{*}{0.875} & \multirow{2}{*}{123.32} & $<.05$ & 2.058 \\
\hline Lg INS & 0.205 & 0.046 & 2.641 & $<.05$ & & \\
\hline Lg WRT & 0.420 & 0.079 & 6.956 & $<.05$ & & \\
\hline -Cons & 12.310 & 1.076 & 8.076 & 0.000 & & \\
\hline
\end{tabular}

Source: Authors' data computation

The result obtained using the Ordinary Least Square (OLS) estimation technique.

$\mathrm{CSR}=12.310+0.339 \mathrm{PDR}+0.205 \mathrm{INS}+0.420 \mathrm{WRT}$

The result in table 1 shows that the predictor variables (i.eProduct delivery, installation and warranty) were significantly joint predictors of customer satisfaction and retention $\left(\mathrm{F}(3,57)=123.32 ; \mathrm{R}^{2}=0.875 ; \mathrm{P}<.05\right)$. The predictor variables jointly explained $87.5 \%$ ofcustomer satisfaction and retention, while the remaining $12.5 . \%$ could be due to the effect of extraneous variables.

It can be deduced from the result obtained that the constant parameter in the long - run is positive.PDR( $\beta=0.339 ; \mathrm{t}=4.623 ; \mathrm{P}<.05) ; \mathrm{INS}(\beta=0.205 ; \mathrm{t}=3.632 .50 ; \mathrm{P}<.05)$ and $\mathrm{WRT}(\beta=0.420 ; \mathrm{t}=$ 6.965; P <.05) were significant independentpredictors of customer satisfaction and retention. This implies that quality product delivery, effective installation (availability of spare parts) and warranty contract on the product will enhance customer satisfaction and retention in the long run. Therefore, the results did not support all hypotheses, which say that product delivery, installation and warranty have no significant effect on customer satisfaction and retention.

\subsection{Implication Of Findings}

All explanatory variables (PDR, INS and WRT) were significantly independent and joint predictors of customer satisfaction and retention. This implies that after sales service dimensions are positively related and significant to customer satisfaction and retention. Moreover, warranty has highest beta $(0.420)$ followed by product delivery and installation $(\beta=0.339$ and 0.205$)$ respectively. This indicates that warranty on the product has highest influence on customer satisfaction and retention followed by product delivery and product installation respectively. The findings agree with previous researches(Ruben, 2012;Saccani, et al., 2007;Gupta and Lehmann, 2007;Raddats, 2011;Alirezaet al,2011;Shaharudinet al, 2009;Muhammed, et al 2011; Goffin and New, 2001) who asserted that after sales service is a marketing tool that enhances and establishes strong and long relationship with customers, which in the long run lead to customer satisfaction, retention and profitability.

\section{Conclusion And Recommendation}

This study examined the impact of after sales service on customer satisfaction and retention with special reference to LG Electronics in Nigeria.Practitioners and researchers agreed that the after sales service plays a major role in satisfying customers as well as increasing number of firms across industries. The study found that after sales service indices (product delivery, installation and warranty) were significantly independent and joint predictors of customer satisfaction and retention. The study also discovered that customers rate warranty contract highest among after sales service dimensions followed by delivery and installation 
respectively. The studyconforms to the positions of Alirezaet al, (2011); Shaharudinet al, (2009); Muhammed, et al(2011); Goffin and New, (2001) andRaddats, (2011). In conclusion, after sales service play important roles in establishing long-term relationships with customers. Furthermore, management of LG Electronics in Nigeria should set up more after sales service departments to the existing ones with experienced staff with the view of developing long term relationship with the customers.

\section{References}

[1]. Ahn, J. S., and Sohn, S. Y. (2009). Customer pattern search for after-sales service inmanufacturing. Expert Systems with Applications, 36(3), 5371-5375.

[2]. Alexander WL, Alexander S, Dayal JJ, Dempsey JD, Vander Ark (2002). The secret life offactory service centres. McKinsey Q., (3):106-115.

[3]. Alireza F, Fatemeh B and Pegah M (2011). How after sales service quality dimensions affectcustomer satisfaction. African journal of business management. 5(17), 7656 - 7664

[4]. Asugman, G., Johnson, J. L., \& McCullough, J. (1997). The role of after-sales service ininternational marketing. Journal of International Marketing, 5(4), 11-28.

[5]. Cavalieri, S., Gaiardelli, P., and Ierace, S. (2007). Aligning strategic profiles with operationalmetrics in after-sales service. International Journal of Productivity and PerformanceManagement, 56(5/6), 436-455.

[6]. Chien YH (2005). Determining optimal warranty periods from the seller's perspective and optimal out-of-warranty replacement age from thebuyer's perspective. Int. J. Syst. Sci., 36 (10): 631-637.

[7]. Cohen MA, Whang S (1997). Competing in product and service: a product life-cycle model.Manage. Sci., 43(4): 535-45

[8]. Cohen MA, Agrawal N, Agrawal V (2006). Winning in the aftermarket.Harv. Bus. Rev., 84(5): $129-138$.

[9]. Cohen MA, Kunreuther H (2007). Operations risk management: overview of Paul Kleindorfer'scontributions. Prod. Oper.Manage.,6(5): 525-541.

[10]. Cohen, M. A., Agrawal, N., \&Agrawal, V. (2006).Winning in the aftermarket.HarvardBusiness Review, 84(5), 129-138.

[11]. Ehinlanwo, O. O., \&Zairi, M. (1996). Best practice in the car after-sales service: Anempirical study of ford, toyota, nissan and fiat in germany - part 1. Business ProcessManagement Journal, 2(2), 39-56.

[12]. Goffin K (1994). Customer support: a cross-industry study of distributionchannels and strategies. Int. J. Phys. Distrib. Log. Manage., 29(6):374-97.

[13]. Goffin, K., \& New, C. (2001).Customer support and new product development. InternationalJournal of Operations \& Production Management, 21(3), 275-301.

[14]. Gupta S, Lehmann DR (2007). Managing Customers as Investments:The Strategic Value of Customers in the Long Run. PearsonEducation as Wharton School Publishing, Upper Saddle River, NJ.

[15]. Kurata, H., and Nam, S.-H. (2010). After-sales service competition in a supply chain:Optimization of customer satisfaction level or profit or both? International Journal ofProduction Economics, 127(1), 136-146.

[16]. Muhammad J.N (2011). Customer information driven after sales service management: Lesion from spare parts logistics. PhD Thesis of Erasmus University Rotterdam.

[17]. Olive, R and Kallanberg R (2003).Managing the transaction from products to service.International journal of service industry management. 14(2), $163-172$.

[18]. Raddats, C. (2011). Aligning industrial services with strategies and sources of marketdifferentiation. Journal of Business \& Industrial Marketing, 26(5), 332-343

[19]. Rigopoulou I, Chaniotakis I, Lymperopoulos C, and Siomkos G (2008).After-sales service quality asan antecedent of customer satisfaction.The case of electronic appliances.Manag.Serv.Qual., 18: 512-527.

[20]. Rosen D and Surprenant .C (1998). Evaluating relationships: Are satisfaction and qualityenough? International journal of service industry management. 9(27), $103-125$.

[21]. Ruben J (2012). Managing after sales services: Strategies and inter firm relationships. PhD Thesis of Diph-Kfm Technic., Universitatstuttgat.

[22]. Saccani, N., Johansson, P., and Perona, M. (2007). Configuring the after-sales service supplychain: A multiple case study. International Journal of Production Economics, 110(1-2), 52-69.

[23]. Shaharudin, M R, Yusuf K M, Elias S J and Mangor S W (2009). Factor affecting customer satisfaction in after sales service of Malaysian electronics business market. Canadian journal of social science. 5(6), $10-18$.

[24]. Slater, S. F. (1996). The challenge of sustaining competitive advantage.Industrial MarketingManagement, 25(1), 79-86

[25]. Urbaniak, A. J. (2001). After the sale: What really happen to customer service. AmericanSalesman, 46(2), 14-17. 